\title{
The Horizon in The God of Small Things by Arundhati Roy: A Poetics of Lines
}

\section{Elsa Sacksick}

\section{Q OpenEdition}

1 Journals

Electronic version

URL: https://journals.openedition.org/ces/8312

DOI: $10.4000 /$ ces.8312

ISSN: 2534-6695

Publisher

SEPC (Société d'études des pays du Commonwealth)

\section{Printed version}

Date of publication: 1 September 2010

Number of pages: 81-91

ISSN: 2270-0633

\section{Electronic reference}

Elsa Sacksick, "The Horizon in The God of Small Things by Arundhati Roy: A Poetics of Lines",

Commonwealth Essays and Studies [Online], 33.1 | 2010, Online since 11 December 2021, connection on 20 January 2022. URL: http://journals.openedition.org/ces/8312 ; DOI: https://doi.org/10.4000/ces. 8312

\section{cc) (†)}

Commonwealth Essays and Studies is licensed under a Licence Creative Commons Attribution - Pas d'Utilisation Commerciale - Pas de Modification 4.0 International. 


\section{The Horizon in The God of Small Things by Arundhati Roy: A Poetics of Lines}

The question of borders, and how they are constantly blurred, lies at the heart of The God of Small Things, not only as regards the identity of the main characters and the social boundaries of castes, but also with respect to the novel's narrative pattern and Roy's creative experimentations with the English language. In The God of Small Things, the horizon can be apprehended as a boundary, a line separating the land and the sea from the sky, but also joining them, since it is the place where they seemingly meet. The horizon will thus be analysed as a geometrical line in its relation to both horizontality and verticality, and also as a boundary. Although the horizon is literally absent from the novel, it becomes re-inscribed on the figurative level, and subsequently becomes a place for transgression and creation, inscribing a Deleuzean line of flight for language to follow and reinvent itself.

7 he horizon conjures up paradoxical notions. Being the ultimate visible element in the landscape, it refers literally to what limits the sight but also, metaphorically, to the opposite idea: the notion of unlimited open space, the promise of something new. The very notion of horizon rests upon a dialectic between the visible and the invisible that lies just behind it, between here and beyond, but also between space (it is a line in space) and time, as the horizon always goes on a par with the idea of the future. Maybe the most significant paradox underlying the notion is that the horizon separates the sky from the earth (or from the sea), yet it also coincides with the line where they meet. In other words, the horizon is a boundary, both a dividing and a meeting line, a place of friction. This aspect is particularly significant in a novel written in India where the border, or the partition line, has become a haunting issue. In her article "Step Across this Line': Edges and Borders in Contemporary Indian Literature," Vanessa Guignery has thoroughly analysed the impact of the dividing line in contemporary Indian literature, and its relation to postcolonial discourses. She relies on several contemporary novels, among which The God of Small Things features prominently, to highlight how the political and social questions of the line are constantly at stake, whether to set up strict delimitations, or to delineate shifting spaces of transgression.

The horizon is surprisingly absent from The God of Small Things. This is dramatically true on the literal level, but also from the point of view of narrative, even if, as we shall see, the horizon subsequently becomes re-inscribed on another, figurative level. In terms of setting, the landscape is often reduced to close and enclosed spaces; no vast stretch of land opens on a far away horizon. 
The first description in the incipit sets the tone, as the depth of field is blurred by the monsoon rain. Each description of the landscape re-enacts the same lack of depth. Whenever the horizon is mentioned, it is immediately blocked by the rain or concealed by night. It is interesting to note that the sky is only present indirectly, through comparisons or reflections on other surfaces. Apart from the painted sky in the church and the omnipresent "sky-blue" colour, the sky is repeatedly glimpsed in its reflection on water or comically reflected in a dog's testicles: "As Khubchand lay dying on his cushion, Estha could see the bedroom window reflected in his smooth, purple balls. And the sky beyond. And once a bird that flew across." (5) On the rare occasions when the word "horizon" occurs, it is used as a metaphor expressing the imposition of limits.

Significantly, the characters rarely watch the horizon. Instead their eyes are focused on "Small Things" - minute details such as the life of insects - so that they are rarely seen to look forward or far away. The narrative abounds in examples showing striking elaborations on the tiny visual details to which the children are attentive. Estha, while retching, is staring at a basin: "The basin had steel taps and rust stains. A brownwebbed mesh of hairline cracks, like the roadmap of some great intricate city. Thoughts hovered over the ... Basin City. But the basin men and basin women went on about their usual basin business. Basin cars, and basin buses ... basin life went on." (108) Although the scope is limited to a small basin in a public toilet, the character's imagination broadens the perspective, so that the idea of the horizon is to be found on a symbolic rather than on a literal level. In The God of Small Things, descriptions rarely embrace a vast horizontal expanse, but jump from one tiny detail to another. The incipit already discloses this preference for discontinuous details and for vertical lines over horizontal ones through the image of the pouring rain: "slanting silver ropes slammed into loose earth," a syntagm in which alliterations in [1] re-enact the same verticality on the micro level of the letter. As a result, the opening description follows a visual, vertical trajectory, leading the eye from the sky to the earth - down the electric poles -, and from the roof of the house down the walls to the "undergrowth" of the garden. ${ }^{1}$

The prevalence of verticality over horizontality intervenes as another manifestation of the absence of horizon, a feature which will have remarkable structural consequences. Indeed, verticality turns out to affect the narrative as much as the syntax. Just like the characters, who are deprived of any hope and therefore of any symbolic horizon, the narrative offers no perspective and no horizontal development either. The narrator describes the twins as drifting through life, without a horizon or a landmark to hold on to: "she left them spinning in the dark with no mooring." (191-192) The spinning metaphor, which becomes recurrent, is directly opposed to horizontality. The children's lives do not unfold along a horizontal line projecting into the future, but are tied

1 The same visual verticality prevails in chapter $18,303-305$. 
to the past, continually looping backwards. The same is true of the narrative which offers no foray into the future, since the narrator never mentions what will happen after the three days in 1993. Roy even murders any idea of the future at the end. Although "tomorrow" is the very last word of the novel, its meaning is emptied of all substance: the reader already knows that Velutha, to whom the word is addressed, will die on the next day. The future branches into the past for the characters, and for the reader, too, since the circumstances of Velutha's death have already been disclosed. This example also reveals that definitive conclusions cannot hold in a novel entirely based on ambiguity and the whetting of the process of interpretation. No matter how dramatic this ending may be, it provides no proper closure, for it ends the narrative with the middle of the story, that is, the beginning of the love affair between Ammu and Velutha. It could also be interpreted as introducing a happy note in a tragic story, launching the novel afresh by inviting its reader to start the narrative from this point once again. ${ }^{2}$

As a result, a spinning dynamics replaces the possibility of a horizontal, chronological development of the narrative. The novel positions 1993 as its starting point, but it returns incessantly to a diegetic past beyond the beginning. The ending of the story is revealed from the first pages, and narrative progress subsequently deconstructs any teleological linearity, as it moves through the detours of the past (1969) and ends just before the tragedy in the middle of the plot - Ammu's love affair with an Untouchable in 1969. Instead of following a linear progression, the narrative actually folds upon itself into an endocentric spiral, reminding us of the spiral guiding the twins' lives. Roy herself refers to "the broody, introspective, circular quality of the narrative" (Interview 89), an image totally opposed to that of the open horizon, and she makes a recurrent use of the root metaphor of the spiral. In other words, the absence of horizon for the characters is transferred onto the narrative through the absence of horizontality. In addition, even the time pattern challenges horizontality through the constant use of flashbacks, which superimpose a vertical paradigm of repetitions upon the syntagmatic unfolding of narrative, thus echoing the vertical lines drawn in visual descriptions. The complex system of flashbacks and flash-forwards further contributes to the disruption of any chronological linearity, and readers themselves are disorientated, as their reading is deprived of any narrative horizon. The flashbacks reorganise the narrative according to the random meandering of memory. Because every detail in the present $-\mathrm{a}$ notebook, Ammu's bedroom, a spider - conjures up the past, the narrative does not progress in a chronological order but rather by associations of ideas, through substitution rather than through contiguity. It therefore obeys what Jakobson would call a paradigmatic, i.e. vertical dynamics rather than a syntagmatic, i.e. horizontal one. Like the twins, the narrative is trapped in traumatic memories, in a "Frozen Time" (160), and nothing really happens in the present. It seems to be trapped in what Deleuze and Guattari call "a dead time":

2 For an analysis of the ambiguous closure of the novel, see Madhu Benoit's article. 
It is there where nothing takes place, an infinite awaiting that is already infinitely past, awaiting and reserve. This dead time does not come after what happens; it coexists with the instant or time of the accident, but as the immensity of the empty time in which we see it as still to come and as having already happened, in the strange indifference of an intellectual intuition. (Deleuze and Guattari 1994, 158)

Such an apprehension of time stresses the paradigmatic notion of concomitance or simultaneity which prevails over that of chronology. The obsessive work of leitmotifs also contributes to undermining horizontality insofar as repetition breaks linearity into a circle. The narrative bristles with repeated sounds, words, sentences, even scenes which start to trace a vertical line on which the repetitions - or paradigms - pile up. Phrases such as "a cold moth with unusually dense dorsal tufts," or "Sicksweet. Like old roses on a breeze," are repeated throughout the novel, and only become meaningful at the end of the narrative. Peter Brook underlines the cohesive power of repetition, which he associates with the dynamics of the paradigm rather than with the syntagm: "Repetition in all its literary manifestations may in fact work as a 'binding,' a binding of textual energies that allows them to be mastered by putting them into serviceable form, usable 'bundles' within the economy of the narrative [...] that allows us to bind one textual moment to another in terms of similarity or substitution rather than contiguity." (Brook 124)

Even the sentence seems to free itself from horizontality. The preference for a paradigmatic composition also operates in the syntax, which is made to resist the syntagmatic rule of contiguity. Punctuation signs proliferate in the sentence and disrupt the linear unfolding of the syntax. Words are no longer contiguous but drift apart:

He thought Two Thoughts, and the Two Thoughts he thought were these:

a) Anything can Happen to Anyone

And

(b) It's best to be prepared. $(194,267,328)$

In similar instances, sentences are cropped short like the depth of the landscape, none of which has a horizon. In parallel, the proliferation of inversion devices, such as anacoluthon, hyperbaton, palindrome and chiasmus contributes to replacing the syntagmatic rule of linear succession by a backward movement, as in the following dislocation: "all day they slept, the bats." (307) In the following example of antimetabole: "Nothing mattered much. Nothing much mattered. And the less it mattered, the less it mattered," (19) the sentence obeys an oscillating rhythm and turns into a circle; it leads nowhere, and once more becomes horizon-less.

Finally, the sentence, horizontal par excellence, is literally reorganised along a vertical axis on the page in examples close to calligrams:

Nothing.

On Rahel's heart Pappachi's moth snapped its sombre wings. 
Out.

In.

And lifted its legs.

Up.

Down. $(293)^{3}$

The vertical structure can take the form of an acrostic, as in the following single acrostic the initial letters of which spell POLICE:
Politeness
Obedience
Loyalty
Intelligence
Courtesy
Efficiency (304)

As a result, any "horizon structure" (as a continuous open horizontal line) is systematically undermined and replaced by verticality. This is true of the narrative and the syntax, both of which are highly discontinuous and tend to become reorganized along a paradigmatic axis, but also of time, which is circular.

Although the economy of the novel is ruled by a denial of horizontality, although its landscape and characters are similarly deprived of any perspective, the horizon is re-inscribed in the novel figuratively through the metaphor of the boundary. The image of horizon, the in-between line dividing the earth from the sky, and, at the same time, the "blurry end" where they seemingly meet, is strikingly relevant in a novel hinging on liminal spaces and states. In The God of Small Things, dividing lines are constantly traced to separate categories, yet the same lines are constantly crossed and tampered with, to the effect that, as first announced in the incipit, "boundaries blur." (1) Because all borders are transgressed, categories seem to leak into one another as in the seminal image of the family jam: "neither jam nor jelly, an ambiguous, unclassifiable consistency." (30) The whole novel abides by this definition, poised in an in-between, along a blurred line, shaped by the friction of opposites and mutually exclusive categories. Classification problems curse the Ipe family as evinced in the labelling of jam, ${ }^{4}$ or the naming of the grandfather's moth: "[T]his difficulty that their family had with classifications ran much deeper than the jam jelly question. They all tampered with the laws that make grandmothers grandmothers, uncles uncles, mothers mothers, cousins cousins, jam jam, jelly jelly." (31) This aspect is also showcased through the recurrent use of binary structures that draw a blurry line between the opposites in which the twins are entrapped: "not old, not young, a

3 See the discussion of hyperparatactic word sentences and single-sentence paragraphs in Marta Dvorak's article.

4 Also see Florence Cabaret's investigation of the taxonomical dynamics of the novel and of the banana jam's synecdochic function, as well as Sacksick's observations in "The Aesthetics of Interlacing in The God of Small Things." 
viable-diable age" (e.g. 3); "not death, just the end of living" (164); "somewhere between indifference and despair" (19); and "poised forever between the terror of war and the horror of peace." (19) As a result, the blurring of the dividing line runs throughout the novel, and operates in conjunction with the writing itself.

Not only does the line between the past and the present blur, but so does the line separating reality from the imaginary, a distinction the children do not make. They reinterpret reality with an animistic and poetic vision which brings the novel to flirt with magic realism. In addition, the social line delimiting castes is transgressed because of the love affair between their mother, a Syrian Christian, and an Untouchable man. Finally, the line separating the twins is also blurred on a symbolic level as they are depicted as "physically separate but with joint identities." (2) After their incestuous reunion, the moral line separating sisters from brothers is similarly erased. Rahel rightly remarks: "perhaps Ammu, Estha and she were the worst transgressors [...] they all broke the laws of who should be loved and how. They all crossed into forbidden territory." (31) The horizon is thus omnipresent on a figurative level if it is apprehended as both a "Blurry End" and a blurring line.

Because the twins in particular keep stepping (and stumbling) across the line, they seem to inhabit that borderline space. They are described in terms that emphasize their in-betweenness - "penumbral shadows between two worlds," (44) standing "forlornly at the edge of the driveway, at the periphery of the Play," (184) as if they embodied these "short creatures patrolling the blurry end." (3) It is as if they were denied the right to occupy a physical place: they have "no locus stand I," and finally they experience "not death, just the end of living." (45) The horizon, an immaterial place having no geographical location, becomes in a way the only place they are allowed to stalk or to haunt. If the horizon is not visible in this novel, it might be precisely because they stand on it. In this respect, Estha conjures up the image of Walking Man, the gaunt sculptures by Giacometti which have the strange characteristic that they seem to remain far away even when one of them approaches, as if they were walking on the horizon. Estha, who "started his walking. He walked for hours on end" (12), who remains unreachable, is subjected to the same whittling process as the sculptures, as he always seems to be on the verge of disappearing: "he had acquired the ability to blend into the background [...] to appear almost invisible to the unstrained eye [...] Estha occupied very little space in the world." (10) Like the sculptures by Giacometti, Estha seems to stalk the horizon.

But it is first and foremost as regards language that the line is blurred, and becomes a fertile meeting point. The line between English and Malayalam is made to grow thinner and thinner, as the twins wander in the interstice between the two languages. ${ }^{5}$ For instance, they transfer the agglutination device of Malayalam into English to create innumerable compound words such as "Ammu's trying-not-to-

5 On this matter see Geetha Ganapathy-Doré and Guillaume Cingal in Gallix. 
cry mouth," (300) "child-sized coffin. Satin-lined. Brass-handle shined [...] Madein-England go-go bag," (4) or "there was a short, Sad-about-Joe Silence." (173) The hyphen is ubiquitous in the novel, and it could then be apprehended as a visual metaphor of the horizon, both separating and joining two words. Other examples of proper agglutination are recurrent as in the following: "lemontoolemon," "echoing stationsounds [...] stationlights," or "CocaColaFantaicecreamrosemilk" $(105,300,301$ respectively). The frontier separating grammatical categories is made porous. Categories meet and mix to give birth to new words. Nouns are turned into verbs, an effect which counterbalances the systematic suppression of verbs in the novel: "the yellow wasp wasping," (201) "Ammu moonwalked him to the toilets," (108) "a thin ribbon of thick water that lapped . . . at the banks on either side sequinned with the occasional silver slant of a dead fish" (124, my emphasis). Likewise, adjectives or nouns blur into adverbs: "a redly dead," "a sadly swirl," or "roos moved cemently." $(31,194,139)$

The same dynamics operates at the level of sound. The oral boundary between words is erased in the poem, originally by Walter Scott, proudly recited by Comrade Pillai's son:

$\mathrm{O}$ young Lochin varhas scum out of the vest

Through wall the vide border his teed was the bes;

Tand savissgood broadsod heweapon sadnun,

Nhe rod all unarmed, and he rode all lalone. (271)

In this comic recitation and re-interpretation of "Lochinvar" by a Malayalamspeaking child, words are phonically fused into a line that runs on the horizon of the English language. ${ }^{6}$ Seen from a distance, segments aggregate into new units so that new words and meanings emerge. The word "scum" is suddenly made salient, or the word "sad nun" which could refer to Baby Kochamma. The twins keep exploring the oral chain as a blurred line. Doing so, they make language proliferate through fusions and frictions like "Ousa the Bar Nowl" (from the Barn owl). Similar instances abound as "He's a filmactor she explained' [...] making Adoor Basi sound like a Mactor who did occasionally Fil." (144) As a place of friction between distinct identities, the horizon embodies a place of transgression but also of creation.

Although the novel allows no horizon, and therefore no possibility of escape for its characters, a flight line can be discerned at another level, specifically in the way Roy handles language and its constraints. The concept of the line of flight is

6 See M. Dvorak's discussion of intensification through syntactic violation, derivation, syllabification, and dislocation, in which she notably identifies this sequence as "a subcategory of arbitrary substitution that Paul Valéry dubbed 'parrot,' consisting in a discourse suffused with tension between new material and material familiar to the receptor's unconscious, and the tacit invitation that the listener work out the 'trick'" (53). 
crucial in Deleuze and Guattari's geophilosophy ${ }^{7}$ where the ligne de fuite is not to be understood as a running away from but rather as a bursting out of, much in the same way as a pipe leaks:

To flee is not to renounce action: nothing is more active than a flight $[\ldots]$ It is also to put to flight $[\ldots]$ to put something to flight, to put a system to flight as one bursts a tube [...] Anglo-American literature constantly shows these ruptures, these characters who create their line of flight, who create through a line of flight. (Deleuze 1987, 27)

The proliferation of metaphors characteristic of Roy's novel may be viewed as another manifestation of the flight line since metaphor displaces meaning which it literally carries over onto another word. Through a semantic transfer, the trope causes an opening in, or a "bursting out of" ordinary language. For instance, descriptions of Rahel in her new dress broaden the perspective on the little girl, and cause meaning to proliferate: "A mosquito on a leash. A Refugee Stick Insect in Bata sandals. An Airport Fairy." (300, 172) Roy's use of the English language is that of the writer who, to quote Deleuze again, "will make language shoot along, and will make us this stranger in our language." (1987, 59) Her distinctive style has been said to stretch the rules of syntax, and to place language on the horizon of grammaticality. As an Indian novelist writing in English, Roy can be considered to have opened new horizons for language. ${ }^{8}$ Her manipulation of English also evokes Deleuze's comment on British and American writers who "make the language take flight, they send it racing along a witch's line, ceaselessly placing it in a state of disequilibrium, making it bifurcate." (1997, 109) Roy also places language on a witch's line to expand the possibilities of language. She explores the other side of the horizon of language which Lacan calls "le reste," i.e. the remainder that exceeds rationalizing discourse. Jean-Jacques Lecercle further elaborates on this notion which he defines in his turn as the operations of grammar pushed to its extreme limits (Lecercle 67). He further explains that with the remainder, language seems to have a life of its own. It speaks, follows its own rhythm, its own partial coherence, and proliferates in a seemingly chaotic and sometimes violent way. ${ }^{9}$ The remainder surfaces in the twins' distinctive use of the English language, which they reinvent by following

\footnotetext{
7 See Catherine Lanone for further discussion of Deleuze and Guattari's line of flight as an exegetical aid to Roy's novel (130-131).

8 One can note, however, that criticism addressing transnational and intracultural dialogism has identified certain aspects of echo and derivation in Roy's novel with respect to Salman Rushdie, whose novel Midnight's Children was a watershed for Indian literary writing. See the discussion in Dvorak.

9 The original text I have paraphrased reads as follows : "le reste c'est la langue qui parle: elle suit son propre rythme, sa propre cohérence partielle, elle prolifère de façon apparemment chaotique et parfois violente." (Lecercle 6)
} 
the very logic of the morphology of English: "Margaret told her to stoppit. So she Stoppitted" (141, 300); and an egg that is "quarter-boiled." (104)

Roy seems to write from the horizon, a metaphoric place recalling the existence of the remainder which, as Lecercle argues, is closely linked to borders and could be best described as a no man's land outside the law. ${ }^{10}$ The horizon abides by the same definition. It is indeed a no man's land that cannot be reached, it is an evershifting line that cannot be fixed and mapped, since it is endlessly redefined as one approaches it. Because it is subjected to processes of deterritorialization and reterritorialization, the horizon can be envisaged from a Deleuzean perspective. As an elusive migrant line, it also shares the liminal characteristics of the nomadic space: "A path is always between two points, but the in-between has taken on all the consistency and enjoys both an autonomy and a direction of its own. The life of the nomad is the intermezzo. (Deleuze \& Guattari 2004, 380) ${ }^{11}$ The horizon bears evidence to the in-between as a zone energized with tensions, a place for becoming. "The middle is not an average," Deleuze and Guattari emphasize, "it is fast motion, it is the absolute speed of movement. A becoming is always in the middle. One can only get it by the middle. A becoming is neither one nor two, nor the relation of the two; it is the in-between, the border or line of flight or descent running perpendicular to both." $(2004,323)$

It is precisely because it coincides with an in-between rather than with a beyond that the horizon is such a seminal notion in The God of Small Things. The horizon underlies in several crucial ways the aesthetics and poeisis of a novel in which there is no beyond, because time and place have become constricted. The characters are trapped in a series of interstices from which language is made to proliferate, an image connoted with hope: "small cracks appeared which would grow and grow." (140) Language itself is not beyond grammaticality, but it explores the malleability of the English language from its inside cracks. The image of the horizon helps us understand that the other side of language is not beyond language but within language. In the novel, the horizon intervenes as a fertile in-between, when it is considered as a flight line causing a bursting out of linguistic conventions or a proliferation of language, but also when it throws into relief the remainder, the "blurry end" from which language is endlessly reinventing itself. The structural function of the horizon in Roy's novel is likely to evoke for many Homi Bhabha's "Third Space." This conjunction brings me to conclude that the horizon could very well be apprehended as a natural metaphor for the postcolonial field. First,

10 "Le reste [...] concerne les frontières; son lieu de prédilection est le terrain vague: l'unique territoire qui échappe vraiment à toute règle est un no man's land." (Lecercle 106)

11 The horizon shares a number of its characteristics with Deleuze and Guattari's nomadic space, also a smooth, open space, only marked by lines that vanish and move along with any trajectory $(1980,472)$. It is also convergent with their definition of the line of becoming which "has neither beginning nor end, departure nor arrival, origin nor destination [...] it is a no man's land.” (2004, 323) 
because it is precisely the line that runs between the East and the West, but also because it evokes that very "post space," as Bhabha understands it, that is "neither a new horizon nor a leaving behind of the past" (1-2), much less a beyond than an in-between.

It is interesting to remark that the incipit of The Satanic Verses by Rushdie confirms this intuition of the horizon as a postcolonial place of becoming and of creations. Indeed, it is precisely when Saladin and Gibreel are floating between the sky and the earth (after the initial explosion of the plane) that mutations occur, and not only linguistic ones. In the amorphous in-between place (earth/sky, India/England) the two characters experience the physical blurring of frontiers: they blend into one another; one is turned into a goat, and this will lead to the birth of a new identity. Rushdie analyses the frontier as a horizon, a shifting line to be explored: "this new permeable post-frontier is the distinguishing feature of our times [...] This is the dance of history in our age: slow slow, quick quick, back and forth and from side to side, we step across these fixed and shifting lines." $(2002,425)$ He places it at the heart of the postmodern and postcolonial identity but also at the heart of the literary process:

Sometimes we feel we straddle two cultures $[. .$.$] that we fall between two stools.$ But however ambiguous and shifting this ground may be, it is not an infertile territory for a writer to occupy. If literature is in part the business of finding new angles at which to enter reality then $[. .$.$] our long geographical perspective, may$ provide us with such angles. $(1991,15)$

The horizon represents the fertile territory of mixing and overlapping, and is precisely an "imaginary homeland": it is a chimera that arouses the imagination. As a place of friction, the horizon is also, ultimately, the place of fiction.

Elsa SACKSICK

Université de Paris 8

\section{Works Cited}

Baneth-Nouallhetas, Emilienne. The God of Small Things: Arundhati Roy. Paris: Armand Colin / CNED, 2002.

- . "Cet obscur objet du désir: la transgression dans The God of Small Things." Etudes anglaises 55.4 (2002): 435-443.

Benoit, Madhu. "Narrative Techniques." Arundhati Roy: l'hybridité célébrée. Ed. F. Gallix. Reims: Mallard, 2002. 96-108.

Bнавна, Homi. The Location of Culture. London: Routledge, 1994.

ВRоок, Peter. Reading for the Plot. Oxford: Clarendon P, 1984.

Cabaret, Florence. "Classification in The God of Small Things." Reading Arundhati Roy's The God of Small Things. Ed. Carole \& Jean-Pierre Durix. Dijon: EU de Dijon, 2002. 75-90. 
Cingal, Guillaume. "Bubbles, Babblers and the Tower of Babel." Arundhati Roy: l'hybridité célébrée. Ed. F. Gallix. Reims: Mallard, 2002. 88-95.

Deleuze, Gilles. Dialogues II. Trans. H. Tomlinson and B. Habberjam. London: Athlone P, 1987.

-. Essays Critical and Clinical. Trans. D.W Smith, M.A. Greco. Minneapolis: Minnesota UP, 1997.

Deleuze, Gilles, et Félix Guattari. Mille Plateaux. Paris: Editions de Minuit, 1980.

-. A Thousand Plateaus. Trans. Brian Massumi. London and New York: Continuum, 2004.

- What is Philosophy? Trans. G. Burchell and H. Tomlinson. New York: Columbia UP,1994.

D’souza, Florence. "Breaking the Rules." Arundhati Roy: l’hybridité célébrée. Ed. F. Gallix. Reims: Mallard, 2002. 151-68.

Dvorak, Marta. “Translating the Foreign into the Familiar: Arundhati Roy's Postmodern Sleight of Hand." Reading Arundhati Roy's The God of Small Things. Ed. Carole \& Jean-Pierre Durix. Dijon: EU de Dijon, 2002. 41-61.

Guignery, Vanessa. "'Step Across this Line': Edges and borders in Contemporary Indian Literature.” Etudes Anglaises 62.3 (2009): 305-316.

Lanone, Catherine. "Seeing the World through Red-Coloured Glasses: Desire and Death in The God of Small Things." Reading Arundhati Roy's The God of Small Things. Ed. Carole \& Jean-Pierre Durix. Dijon: EU de Dijon, 2002. 125-143.

LeCERCLe, Jean-Jacques. La violence du langage. Paris: PUF, 1996.

Roy, Arundhati. The God of Small Things. London: Flamingo, 1997.

—, and Taisha Abraham. "Interview with Arundhati Roy." Ariel 29.1 (1998): 89-92.

Rushdie, Salman. Imaginary Homelands. London: Granta Books, 1991.

-. Step Across this Line: Collected Non-Fiction 1992-2002. London: Jonathan Cape, 2002.

Sacksick, Elsa. "The Aesthetics of Interlacing in The God of Small Things." Reading Arundhati Roy's The God of Small Things. Ed. Carole \& Jean-Pierre Durix. Dijon: EU de Dijon, 2002. 63-73. 